\title{
PROPAGATION OF MANIPURI DANCE TO THE WORLD
}

\author{
Yaikhom Hemantakumar 1, Laishram Hemantakumari Devi 2 四 \\ ${ }^{1}$ Senior Professor in Manipuri Dance, Department of Rabindra Sangit, Dance and Drama \\ Sangit Bhavan, Visva Bharati University, Santiniketan , West Bengal, India \\ 2 Laishram Hemantakumari Devi, Research scholar in Manipuri Dance, Visva Bharati University, \\ Santiniketan, India
}

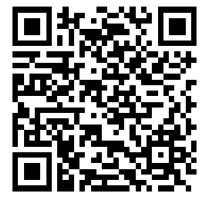

DOI: https://doi.org/10.29121/granthaalayah.v9.i3.2021.3780

Article Type: Research Article

Article Citation: Yaikhom

Hemantakumar, and Laishram

Hemantakumari Devi. (2021).

PROPAGATION OF MANIPURI

DANCE TO THE WORLD.

International Journal of Research -

GRANTHAALAYAH, 9(3), 128-131.

https://doi.org/10.29121/granthaa

layah.v9.i3.2021.3780

Received Date: 27 February 2021

Accepted Date: 26 March 2021

Keywords:

Propagation

Manipuri Dance

World

\begin{abstract}
The then Manipur was a sovereign state ruled by a lineage of many kings. Inspite of being situated in a far, isolated place from other lands and countries and also surrounded by ranges of hills with thick forestation, the inhabitants of this place faced untold hardship in communicating with other external lands and countries. But the state is now recognised by the outside world due to its rich storage of custom, tradition and culture of dance and music.
\end{abstract}

\section{INTRODUCTION}

Indeed, it is very surprising and happy when we think of the matter. That we cannot but remember afresh and count the Universal poet Guru Rabindranath Tagore, the descendants of king of Tripura and Miss Luis Lightfoot of Australia and all dedicated and pioneer preceptors in the field of dance.

It has been proved from the records in the history that Manipur had been in touch with the Britishers since the beginning of the $19^{\text {th }}$ (nineteenth) century. There had been evidences of intermarriages of the Manipuris with the Britishers. There are nuptial records of Borosaheb Ongbi Sanatombi with Major Maxwell. The first Nitya Raas Dance is said to be introduced during the time in which Sanatombi herself played the role of 'Makok Chingbi' (leading dancer) for the dance which was performed in the presence of many British officers and nobles of Manipur. We have found clear evidences of stories that since the mid-19th century A.D. the British officers in Manipur accompanied and guided the artistes of Manipur to travel at Burma, Hong Kong and Brtitish Colonial countries for exhibition of Manipuri dance and music there. But a question of eagerness arises that how far the exhibits in those performances of the art in that time closely associated with our real traditional amusement.

During the royal tenure of His Highness Chandrakirti Maharaj i.e. 1850-90 A.D. in Manipur, the intrusion of Kathak Dance, the Gharana of Mathura and Jaipur from outside this land became very popular to the audience during the above period. With imitations of some styles of the above dances, a kind of dance performance known as Marbak 
Jagoi was also prevalent popularly during that time. On the other hand, the Lai Haraoba Jagoi, a very ancient traditional dance of Manipur and Jagoi-Raas were allowed by the British officers to be performed in public amusements from time to time. But the learned persons gave their views that the present appearance or form of dances what we see today had been originated from the time of the advent of the $20^{\text {th }}$ century A.D. The matured form of performance of Manipuri dance became prevalent since the second half of the $20^{\text {th }}$ century.

As such, it may be an exaggeration to state that the then performances of the Manipuri dance as arranged by the British officers for exhibition outside Manipur and other foreign countries including British Colonial countries to be similar with the form of dance which is prevalent nowadays. The learned persons gave their positive views that the first effort to identify the Manipuri Jagoi (dance) to the world was made by Kavi Guru Rabindranath Tagore.

It is said that Kavi Guru first saw Manipuri Jagoi at Sylhet. Later on, Rabindranath Tagore had witnessed Manipuri Jagoi many times in the palace of Maharaja Manik Kishwar of Tripura. For the first time Kavi Guru witnessed amusement connected with Basanta Utsav there.

Further, Nataraj Uday Shankar with philosophical trend of Kavi Guru after repeated experiments arranged for a new kind of dance to become a new form of Manipuri Jagoi suitable for presentation to the world. Thus, Guru Maisnam Amubi, the then renowned Guru in Manipuri Jagoi and Yambem Mahavir, the young disciple (sevak) of Guru were invited by Uday Shankar to be faculties for the Dance Troupe of Manipuri Jagoi. Thus they worked with Uday Shankar for a long period of time which is found in the records of history. Thus the combination of artistic talent and skill of both Uday Shankar and Guru Amubi had produced a unique form of Manipuri dance in the best possible degree of performance in the presence of art-loving audience comprising of artistes of dance and music, critics and many others from different walks of life in many countries of the globe. Thus a gradual recognition to the Manipuri dance started from all over the world. It is also the credit of Uday Shanker to produce the young talented artiste, Yambem Mahabir as a co-dancer of Uday Shanker before the audience of the world.

Along with the identification of Indian culture to the other countries of the world through the relentless efforts of Rabindranath and Uday Shankar, Manipuri dance has also occupied a reputed place in the cultural sphere of the world. Hence many notable renovators in that field have also been come out from Manipur. Besides knowing gradually the utility, quality and value of this dance to the individuals, it has extended imparting its values in the social life of the people.

Thus, slowly and slowly establishing the groups and institutions of the dancers came into being while citing names of old institutions, the name of Nrityashram, Nartalaya, Kala Bhavan and Manipur Dance College which sprang up in Imphal Town may be mentioned.

But Kavi Guru could not reach Manipur, as such he could not witness the real performance of Manipuri dance. Being reacted with the Basanta Utsav, witnessed in the palace of Tripura in 1916 A.D, Gurudev could avail of witnessing 'Raas Leela dance' on his sixth travel to Tripura in 1926. From the written records it is found that the daughter of the then Maharaja Veer Vikram Manikishwar was leading gopi of the Raas dance. It is believed that the first Raas dance seen by kavi Guru would be the above dance. From an impression made in the mind of Kavi Guru, he requested Maharaja Brajendrakishwar to kindly send a teacher of Manipuri Dance at Santiniketan. In 1930 A.D. a function of reception to the visit of Prince of Wales Sir George V in Calcutta was arranged. Therein, by the order of His Highness Maharaja of Manipur, Churachand Singh, K.C.S.I., C.B.E, a dance troupe from Manipur presented a Raas dance (Jagoi Raas). Kavi Guru also witnessed the above dance which is regarded as his second witness. The mutual relationship between Kavi Guru and king of Tripura began since the rule of Kala Premi Maharaja Radhakishwar Manikya (1896-1909 A.D.) . But, after the first visit of Gurudev at Tripura in 1900 A.D., a relation with Tripura had been started. At the request of Gurudev, a dance teacher of the palace of Tripura, Rajkumar Angousana (Budhimanta) also brother-in-law of Maharaja Brajendrakishwar Manikya was deputed at Santiniketan, the talented and experienced teacher of Manipuri dance and music worked for some time at Santiniketan. After some time, Pangambam Nabakumar Thakur was sent by the Maharaja of Tripura as a dance teacher at Santiniketan in place of Rajkumar Angousana. To fulfil the wishes of Gurudev, Nabakumar started new experiments in dance and music and in 1927 produced the first dance drama, 'Natir Puja' of Gurudev and 'Chitrangada' for the second time. Later, a dance drama, 'Syap Mochon' was produced in 1936.

It has been learnt from historical records that Guru Nabakumar not only worked at Santiniketan but also travelled to other cities of India to spread the art of Manipuri dance. On the invitations from Santiniketan, some teachers from Manipur, like Oja Laishram Kulabidhu (1930), Rajkumar Suryaborosana (1937), Guru Haobam Atomba and Arambam Amubi Singh worked at Santiniketan from time to time. It has been evident to the art lovers of the world that the first centre of propagating Manipuri dance was at Santiniketan. Persons from many places in 
india and foreign countries had the opportunity to witness the Manipuri dance at Santiniketan. But the real and vivid Manipuri dance could not be witnessed by the audience of the world as many of the performances were the creative products of Gurudev Tagore and Uday Shankar.

The first Manipuri dance shown on the stage to the audience of the eastern countries and western countries of the world was initiated by two notable artistes of Manipur viz Sarvashri Rajkumar Priyogopal and Shri Laishram Lokhon Singh in 1950. Mention may be made that a citizen from Australia, Miss Luis Lightfoot made financial investment and arrangement for the eventful functions of stage performance of Manipuri Dance in different cities of Australia during 1950. There are records that performance of Manipuri dance was shown in Japan during 1951 and in America and Europe during 1952. The art lovers of Manipur are credited to Miss Luis Lightfoot and the then leading artistes of Manipuri dance viz Rajkumar Priyogopal and Shri Laishram Lokhon Singh who had taken hard pains and endeavour to produce Manipuri dance for the first time before the audience of the world.

After the visit of the then prime Minister of India, Jawaharlal Nehru to Manipur during 1952, the artistes like Shri Phurailatpam Iboton Sharma (Costume), Shri Chitrasen Singh (Instrument), Shri Babu Singh (Pung), Shri Nodia Singh (Pung), Suryamukhi Devi (Dance) and Smt. Tombinou Devi (Dance) shared in making teams to exhibit or show the Manipuri dance to the foreign countries of the world like Soviet Russia, Poland, Chekoslovakia, Republic of China and other countries of South East Asia etc. during the period of 1954 to 1956 and 1958.

There are institutions, colleges and universities in various cities of India for learning and propagating Manipuri Dance like Parimon Academy, Mumbai of Sobita Mehta ; Manipuri Nartalay, Impha , Mumbai and Calcutta ; Vanasthali Vidyapith, Jaipur ; Anjika, Calcutta and Visva Bharati at Santiniketan. At present, there are a huge number of institutions for Manipuri dance in different places of Manipur valley and adjoining hilly areas. But it seems that the quality and status of this art is degrading in the present trend. So, in order to prosper and enrich our cultural store which had been existed for centuries since the earlier times of ruling kings of Manipur, the artistes and members of respective institutions have to take proper responsibilities for the above cause. Besides, the Department of Art and Culture, Manipur as well as the Government of Manipur may kindly give emphasis in giving proper directives and sufficient financial aids regularly to the growing up and talented artistes and properly functioning institutions in renovating and nourishing the art and culture of this land.

Lastly, and not the least, it is also requested the proper authority that like the artistes, teachers and gurus of Manipuri dance working in Manipur it is also requested to allow to participate and recognize the artistes, teachers and gurus working outside Manipur for the cause of Manipuri dance with giving incentives or awards to them in public functions to encourage their services for the cause of this prestigious art of Manipuri dance.

\section{SOURCES OF FUNDING}

This research received no specific grant from any funding agency in the public, commercial, or not-for-profit sectors.

\section{CONFLICT OF INTEREST}

The author have declared that no competing interests exist.

\section{ACKNOWLEDGMENT}

None.

\section{REFERENCES}

[1] Classical Dance of India - Dr. Kapila Vatsayan

[2] Fragment of Manipuri dance - E.Nilakanta

[3] Spring Solo Festival - Sanakhya Ibotombi PAL 1983

[4] Silver Jubilee Celebration of P.A.C.

[5] Aspect of Indian Culture - E.Nilakanta 
Yaikhom Hemantakumar, and Laishram Hemantakumari Devi

[6] Meitei Phijet Leiteng - Ph. Iboton Sharma

[7] Sangit Natak Journels 